\title{
Giardia lamblia AND OTHER INTESTINAL PARASITIC INFECTIONS AND THEIR RELATIONSHIPS WITH NUTRITIONAL STATUS IN CHILDREN IN BRAZILIAN AMAZON
}

\author{
Filipe Anibal CARVALHO-COSTA(1), Alessandra Queiroga GONÇALVES(1), Sandra Laranjeira LASSANCE(1), Luanda Macedo da SILVA NETO(2), \\ Carla Alexandra Almeida SALMAZO(3) \& Marcio Neves BÓIA(1,3)
}

\begin{abstract}
SUMMARY
The objective of this survey was to assess the relationships between intestinal parasitism, nutritional status and hemoglobin level in children with Indian ascendancy living in an urban area in Brazilian Amazon. We carried out a cross-sectional survey obtaining anthropometric, parasitological and socioeconomic data, and hemoglobin measurements of children aged six to 84 months. Anthropometric data were expressed as z-scores for weight for age (WAZ), height for age (HAZ), weight for height (WHZ) and mid upper circumference for age (MUACZ) parameters. Parasitological examinations were performed through Ritchie $(n=307)$, Kato-Katz $(n=278)$, Baermann-Moraes $(n=238)$ and Safranin-methylene blue methods $(n=307)$. Hemoglobin measurements were obtained with a Hemocue ${ }^{\circledR}$ photometer $(n=282)$. Socioeconomic data were used in order to classify children in three family income strata $(\mathrm{n}=242)$. Multiple linear regression analysis showed independent interactions between Giardia lamblia and WAZ (beta $=-0.195, \mathrm{SE}=0.138, p=0.003$ ), WHZ (beta $=-0.161, \mathrm{SE}=0.133, p=0.018$ ) and MUACZ (beta $=-0.197$, $\mathrm{SE}=0.143, \mathrm{p}=0.011)$, controlling for age, sex, family income, Ascaris lumbricoides, and hookworm infection. Also, the multivariate model showed that the only variable associated with hemoglobin levels was age. Intestinal parasitism control should increase children's possibilities of full development in the studied area.
\end{abstract}

KEYWORDS: Giardia lamblia; Intestinal Parasitism; Nutritional Status; Hemoglobin; Children; Brazilian Amazon; Indians.

\section{INTRODUCTION}

Enteric parasitic diseases lie among the many health problems observed in economically disadvantaged populations of the poorest countries.

Intestinal parasitism has clear social and environmental determinants, with high prevalence in regions with deficiency in sanitation, potable water supplies, education and adequate dwelling conditions. The burden attributed to intestinal parasites has been studied in three domains: growth and ponderous gain deficits, iron deficiency anemia and disturbances of cognitive function ${ }^{4,21}$.

The associations between malnutrition and intestinal parasitism has been demonstrated in cross-sectional surveys involving the correlation between nutritional status and both prevalence and intensity of infections $\mathrm{s}^{7,12,13,17,18,20}$. Those conditions may cause damage to full individual development, affecting even cognitive function and school performance of children ${ }^{4,15}$.

Also, acute complications may occur, often severe and potentially fatal, such as intestinal obstruction, severe anemia and rectal prolapse ${ }^{5}$, observed mainly in infections by high worm burdens, afforded by high levels of exposition observed in the absence of adequate conditions of sanitation and excreta destination.

Undernutrition still represents an important public health problem, mainly in the developing world. Prevalence of chronic malnutrition in children reaches $12.6 \%$ in Latin America, 34.4\% in Asia, 35.2\% in Africa and $32.5 \%$ in all developing countries ${ }^{16}$.

The World Health Organization (WHO) estimates that near two billion people in the world have iron deficiency anemia, characterizing the deficiency of this micronutrient as the commonest on a global scale $^{24}$. The groups most affected in developing countries are schoolaged children and pregnant women, with an estimated prevalence of $53 \%$ in both cases ${ }^{24}$.

The Brazilian Amazon, localized mainly in the North Region, encompasses the majority of national Indian communities. Children's malnutrition in these populations has been described. Contact with national society and abandonment of ancestral practices like hunting and gathering, besides subsistence monoculture agriculture have been related to qualitative and quantitative deterioration of both diet and

Financial support: CNPq, grant 50.7543-2004-1

(1) Laboratório de Doenças Parasitárias - Medicina Tropical, IOC/Fiocruz, RJ, Brasil.

(2) Serviço de Parasitologia, Departamento de Micro-Imuno-Parasitologia, IPEC/Fiocruz, RJ, Brasil.

(3) Disciplina de Doenças Infecciosas e Parasitarias, FCM, Universidade do Estado do Rio de Janeiro, RJ, Brasil.

Correspondence to: Filipe Anibal Carvalho-Costa, Avenida Brasil, 4365, 21045-900 Rio de Janeiro, RJ, Brasil. E-mail: guaratiba@ioc.fiocruz.br 


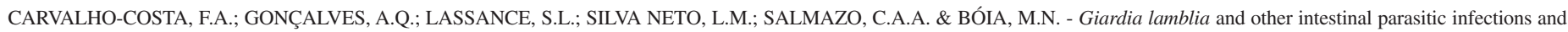
their relationships with nutritional status in children in Brazilian Amazon. Rev. Inst. Med. trop. S. Paulo, 49(3): 147-153, 2007.

nutritional status observed in that societies ${ }^{19}$. In Brazil, the most recent survey at national level for children nutritional status was carried out in 1996. It estimated stunting prevalence of $16.2 \%, 17.9 \%, 5.1 \%$ and $10.5 \%$; and underweight frequencies of $7.7 \%, 8.3 \%, 2 \%$ and $5.7 \%$ in the North, Northeast, South and whole national territory respectively ${ }^{3}$. This shows an important regional variability and suggests that populations living in Amazon have a worst nutritional status when compared with those living in other Brazilian regions.

Urbanization carried out without sanitary and housing infrastructure has been observed in Brazilian Amazon, often producing disease by creation of socioeconomic and environmental conditions to its spread. It's the case of intestinal parasitism and other infectious diseases like tuberculosis, leprae, dengue, leishmaniasis and malaria.

The objective of the present survey was to identify the relationships between intestinal parasitism and nutritional status, including hemoglobin levels, of children with Indian ascendancy living in Santa Isabel do Rio Negro, an urban area in Brazilian Amazon.

\section{METHODS}

Setting: The study was performed in Santa Isabel do Rio Negro, a municipality situated in the northwest of Amazonas State $\left(0^{\circ} 28^{\prime} \mathrm{S}\right.$ and $65^{\circ} 32^{\prime} \mathrm{W}$ ), distant $781 \mathrm{~km}$ from Manaus, the State capital, by fluvial route, in the Alto Rio Negro Region. The majority of the population has Amerindian ancestry. The whole municipality has 10,561 inhabitants. In the heart live 4,220 people ( 720 children aged six to 84 months), distributed in 773 dwellings and six districts ${ }^{8}$. The remaining population is distributed in hundreds of small communities in the backlands of the municipality. Inhabitants of the municipality heart descend from Tukano Oriental (which includes Tukano, Pira-tapuya and Desana groups) and Aruak (Baniwa, Bare and Tariana groups) speaking societies 9 . At present, interethnic marriage is very frequent; the existence of individuals with parents belonging to different groups being common, mainly in the urban area. Sanitary infrastructure is markedly deficient. This study involved the urban population, living in the municipality seat.

Strategy for children recruitment and sampling: Children included in this survey are attended by the non-governmental organization "Pastoral da Criança". This entity belongs to the Brazilian Catholic Church and performs monthly weight measurements of children aged six to 84 months in the heart of the municipality. We carried out meetings with "Pastoral da Criança" local leaderships in order to explain the protocol and objectives of the project. The research team stayed two days in each of the six districts in the city, performing anthropometry and hemoglobin measurements in the Community Centers, with the supervision of "Pastoral da Criança" staff of each district, aiming to cover the entire municipality's seat. The whole population aged six to 84 months (720 children) was invited to participate in the study, but three hundred seven children, (near $42.6 \%$ of the entire population in this age group living in the heart of the municipality) attended the Community Centers during the survey period.

Subjects were included after their parents gave informed consent. The Human Subject Ethics Committee at Evandro Chagas Research
Institute of Oswaldo Cruz Foundation previously approved the research.

Study design and statistical analysis: This cross sectional survey was carried out from $8^{\text {th }}$ to $25^{\text {th }}$ August 2005. Investigators provided plastic fecal collectors without preservatives to the parents and performed anthropometry and hemoglobin measurements. A questionnaire with demographic and socioeconomic information was filled in an interview with children's parents, in order to classify the families in three different socioeconomic strata. These strata where defined by monthly family income. The first was constituted by families receiving more than 266 United States Dollars (USD), corresponding to two Brazilian "minimum wages", the second included families with an income from 133 to 266 USD (one to two Brazilian minimum wages) and the thirst was composed by families with activities that did not involve wages (farmers who practice familiar agriculture). In bivariate analysis, the dependent variables were the anthropometric parameters and hemoglobin level, while independent variables were the intestinal parasitic infections. Means were compared through analysis of variance (ANOVA) and frequencies by the chi-square test. In multivariate analysis, the linear regression model included as independent variables age, socioeconomic status and selected parasitic infections, based on the influence of each one observed on the bivariate analysis. Statistical analyses were performed using the SPSS 9.0 software.

Collection and processing of stool samples: Children's parents were encouraged to return the fecal sample to the field laboratory assembled in the local health unity. Twenty-nine samples had not enough material, so Kato-Katz smears of 278 children were performed in this laboratory. Sixty-nine samples had not enough material to perform the Baermann-Moraes technique, so 238 examinations were made through this method, with fresh stools, in the field laboratory. After these examinations, a preservative (SAF, sodium acetate-aceticformalin) was added to the stool sample, in order to perform the Ritchie and safranin-methylene blue methods $(\mathrm{n}=307)$. All children older than 24 months with a positive examination on Kato-Katz received a single dose of Albendazole and those aged 12 to 24 months received a three-day Mebendazole treatment.

Anthropometric and hemoglobin measurements: Body weight was recorded with a portable electronic scale, to the nearest $100 \mathrm{~g}$. Subjects were barefoot and wore minimum clothing. Infants aged less than 12 months were weighted in their mothers' arms. Height or length was measured using an anthropometer to the nearest $0.1 \mathrm{~cm}$. Mid upperarm circumference was measured with a flexible tape on the left arm, at the midpoint between the acromium and the olecranum. A single person performed all measurements.

Z-scores (standard deviations) from the National Centers for Health Statistics (NCHS) reference values ${ }^{25}$ of height for age (HAZ), weight for height (WHZ), weight for age (WAZ) and mid upper arm circumference for age (MUACZ) were calculated using the NutStat Module on EpiInfo 2000 version 3.2.2. Stunting, wasting and underweight were defined by values equal or below -2 for HAZ, WHZ and WAZ respectively ${ }^{23}$. Severe stunting was defined by a value below -3 for HAZ.

Hemoglobin $(\mathrm{Hb})$ was analyzed using a Hemocue Photometer. Anemia was defined by $\mathrm{Hb}$ values below $11 \mathrm{mg} / \mathrm{dL}$ for children aged 6 


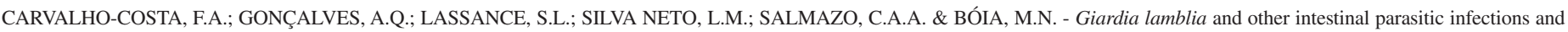
their relationships with nutritional status in children in Brazilian Amazon. Rev. Inst. Med. trop. S. Paulo, 49(3): 147-153, 2007.

to 60 months and below $11.5 \mathrm{mg} / \mathrm{dL}$ for children aged up to 60 months $^{24}$. All ages were obtained from immunization certificates. Anemic children received ferrous sulphate $(5 \mathrm{mg} / \mathrm{kg} /$ day $)$ for a three months treatment. Sample sizes varied for different studied points, since some children refused to take one or more measures.

\section{RESULTS}

Nutritional status and family income grouping: Malnutrition characterized as stunting ( $\mathrm{HAZ}<-2)$, severe stunting $(\mathrm{HAZ}<-3)$ or underweight (WAZ <-2) was observed in $25.7 \%, 3.6 \%$ and $3.7 \%$ of the sample respectively, while $51.1 \%$ of the children had anemia (Table 1). Family income grouping showed that $67.4 \%$ of children belong to families with a monthly income between 133 and 266 USD, that corresponds to one and two minimum Brazilian wages and $14.9 \%$ belongs to families without cash-oriented activities, whose parents are farmers practicing subsistence agriculture (Table 1). Frequencies of stunting, severe stunting and anemia by family income strata are presented in Figure 1. Stunting and severe stunting were significantly more frequent in children belonging to families with no wage.

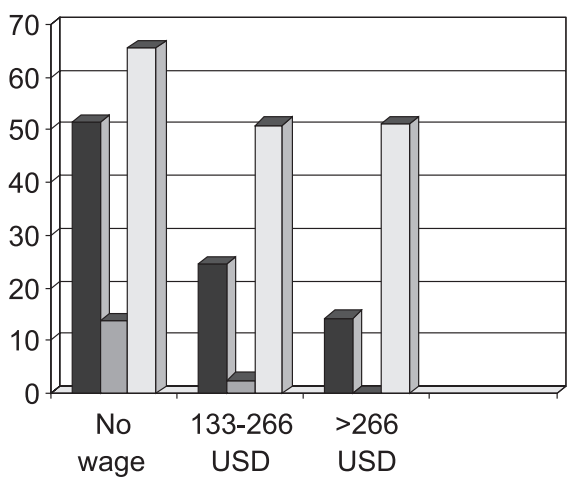

\begin{tabular}{|l}
\hline Stunting \\
$\square$ Severe stunting \\
$\square$ Anemia
\end{tabular}

Fig. 1 - Comparison of frequencies ${ }^{1}$ of stunting, severe stunting and anemia in children living in Santa Isabel do Rio Negro by family income group.

$1-p=0.001 ; p=0.001$ and $p=0.31$ for stunting, severe stunting and anemia respectively (chi-square for trend).

Frequency and intensity of intestinal parasitic infections: Frequencies of intestinal parasitic infections are presented in Table 2, and $77.2 \%$ of subjects were infected with at least one enteric parasite. For A. lumbricoides infection, $29.5 \%$ of the infected children had an egg count below 5,000 eggs per gram (epg) of feces, $44.6 \%$ had a worm burden between 5,000 and 50,000 epg and 25.9\% had a count above 50,000 epg. For trichuriasis, $91.4 \%$ of infected subjects presented a worm burden below 1,000 epg, while $8.6 \%$ of children had an egg count between 1,000 and 10,000 epg. All children infected with hookworms presented an egg count below 2,000 epg. Table 3 shows that infections by A. lumbricoides, hookworm, S. stercoralis and E. histolytica/E. dispar were significantly more common in children belonging to families without wages. Saprophytic protozoa were detected with the following frequencies: $32.6 \%$ for Entamoeba coli, $6.2 \%$ for Iodamoeba butschlii, $8.5 \%$ for Endolimax nana and $5.9 \%$ for Chilomastix mesnili.

Intestinal parasitism and its relationship with nutritional status: Bivariate analysis through ANOVA showed significantly lower means for WAZ, HAZ, WHZ and MUACZ in children infected with G. lamblia, for WAZ and HAZ in children harboring hookworms and HAZ for children with A. lumbricoides infection (Table 4).

Simple linear regression analysis did not show a relationship between intensity of $A$. lumbricoides, T. trichiura or hookworm infections expressed as epg and z-scores of anthropometric parameters.

Table 1

Sample characteristics

\begin{tabular}{lcc}
\hline Characteristic & & $\mathrm{n}$ \\
\hline Gender, \% female & 50.8 & 307 \\
Age groups, months, \% & 307 \\
$6-12$ & 5.5 & \\
$13-24$ & 17.6 & \\
$25-36$ & 15.0 & \\
$37-48$ & 19.9 & \\
$49-60$ & 18.2 & \\
$61-72$ & 16.0 & \\
$73-84$ & 7.8 &
\end{tabular}

Nutritional Status

Stunting ${ }^{1}$ (HAZ <-2), \% $\quad 25.7 \quad 296$

Severe stunting $^{1}(\mathrm{HAZ}<-3), \% \quad 3.6 \quad 296$

Underweight (WAZ <-2), \% $3.7 \quad 397$

Wasting (WHZ <-2), \%

Hemoglobin, mg/dL ${ }^{2} \quad 10.84 \pm 1.30 \quad 282$

Anemia $^{3}, \%$

$51.1 \quad 282$

Indian Language Group ${ }^{4}$

Baré

59.3

Tukano

18

Baniwa

11.3

Pira-tapuya $\quad 7.3$

Tariana 2.7

Desana 1.3

Family income (monthly) ${ }^{5,6}$

No cash-oriented activities

(subsistence agriculture), \%

133 - 266 USD, $\%$

$>266$ USD, $\%$

286

Maternal education

Some elementary or no education $\quad 23.7$

Junior high school $\quad 27.8$

High school $\quad 42.6$

College $\quad 5.9$

1-11 subjects refused to take anthropometric measurements and were excluded of analysis. 2-Value is mean $\pm \mathrm{SD}$. 3- Hemoglobin $<11 \mathrm{mg} / \mathrm{dL}$ for children aged six to 60 months and $<11.5 \mathrm{mg} / \mathrm{dL}$ for children older than 60 months (WHO 1999). 25 children refused the hemoglobin measurement and were excluded of analysis. 4185 children had parents who did not remember the ancestral Indian language group. 5- 65 subjects had missing values for socioeconomic data and were excluded of the multivariate analysis. 6- 133 USD $=1$ Brazilian minimum wage. 


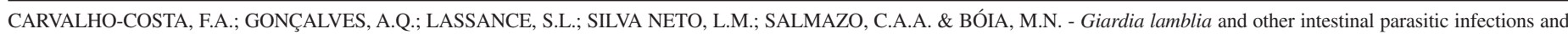
their relationships with nutritional status in children in Brazilian Amazon. Rev. Inst. Med. trop. S. Paulo, 49(3): 147-153, 2007.

Table 2

Frequency of intestinal parasites infection by age group in children in Santa Isabel do Rio Negro, Amazonas, Brazil, $2005^{1}$

\begin{tabular}{|c|c|c|c|c|c|c|c|c|c|}
\hline $\begin{array}{l}\text { Age group } \\
\text { (months) }\end{array}$ & $\begin{array}{c}\text { Ascaris } \\
\text { lumbricoides }\end{array}$ & Hookworm & $\begin{array}{l}\text { Trichuris } \\
\text { trichiura }\end{array}$ & $\begin{array}{l}\text { Strongyloides } \\
\text { stercoralis }\end{array}$ & $\begin{array}{l}\text { Hymenolepis } \\
\text { nana }\end{array}$ & $\begin{array}{l}\text { Giardia } \\
\text { lamblia }\end{array}$ & $\begin{array}{c}\text { Entamoeba } \\
\text { histolytical } \\
\text { E. dispar }\end{array}$ & $\begin{array}{l}\text { Cryptosporidium } \\
\text { spp. }\end{array}$ & $\begin{array}{c}\text { Blastocystis } \\
\text { hominis }\end{array}$ \\
\hline $6-12$ & $1 / 17(5.9)$ & - & - & $1 / 10(10)$ & - & $1 / 17(5.9)$ & - & - & - \\
\hline $13-24$ & $19 / 54(35.2)$ & $3 / 51$ (5.6) & 7/54 (13) & 3/41 (7.3) & - & $11 / 54(20.4)$ & $3 / 54(5.6)$ & $1 / 54$ (1.9) & 6/54 (11.1) \\
\hline $25-36$ & $17 / 46(37)$ & - & $11 / 46(23.9)$ & - & $2 / 46(4.3)$ & $16 / 46(34.8)$ & $3 / 46(6.5)$ & $1 / 46(2.1)$ & $12 / 46(26.1)$ \\
\hline $37-48$ & 24/61 (39.3) & $2 / 61(3.3)$ & $14 / 61(23)$ & $4 / 48(8.3)$ & $3 / 61$ (4.9) & 19/61 (31.1) & $9 / 61(14.8)$ & - & $29 / 61$ (47.5) \\
\hline $49-60$ & $25 / 56(44.6)$ & $3 / 56(5.4)$ & $16 / 56(28.6)$ & 4/43 (9.3) & $2 / 56(3.6)$ & $17 / 56(30.4)$ & 9/56 (16.1) & - & $31 / 56(55.4)$ \\
\hline $61-72$ & $25 / 49(51)$ & $7 / 49$ (14.3) & $18 / 49(36.7)$ & - & $1 / 49(2)$ & $17 / 49(34.7)$ & $9 / 49(18.4)$ & $1 / 49(2)$ & $33 / 49(67.3)$ \\
\hline $73-84$ & $12 / 24(50)$ & $1 / 24(4.2)$ & $9 / 24(37.5)$ & $1 / 19(5.3)$ & $2 / 24(8.3)$ & $8 / 24(33.3)$ & $4 / 24(16.7)$ & - & $9 / 24(37.5)$ \\
\hline Total & $123 / 307$ (40.1) & $16 / 307(5.2)$ & 75/307 (24.4) & $13 / 238(4.2)$ & $10 / 307(3.3)$ & 89/307 (29) & $37 / 307$ (12.1) & 3/307 (3) & $120 / 307$ (39.1) \\
\hline
\end{tabular}

1- Values are positive/performed examinations (\%).

Table 3

Frequency of selected intestinal parasitic infections by family income group in children from Santa Isabel do Rio Negro, Amazonas, Brazil, $2005^{1}$

\begin{tabular}{lcccc}
\hline \multicolumn{5}{c}{ Family income group } \\
\hline Parasite & No wage & $133-266$ USD & $>266$ USD & $p$ (chi-square) \\
\hline Ascaris lumbricoides & $22 / 36(61.1)$ & $67 / 163(41.1)$ & $8 / 43(18.6)$ & 0.001 \\
Trichuris trichiura & $13 / 36(36.1)$ & $36 / 163(22.1)$ & $10 / 43(23.3)$ & 0.20 \\
Hookworm & $4 / 36(11.1)$ & $5 / 163(3.1)$ & - & 0.022 \\
Strongyloides stercoralis & $5 / 30(16.7)$ & $6 / 121(5)$ & $1 / 34(2.9)$ & 0.04 \\
Giardia lamblia & $10 / 36(27.8)$ & $53 / 163(32.5)$ & $11 / 43(25.6)$ & 0.62 \\
Entamoeba histolytica/E. dispar & $9 / 36(25)$ & $16 / 163(9.8)$ & $7 / 43(16.3)$ & 0.04
\end{tabular}

1- Values are positive/performed examinations (\%).

Table 4

Comparison of anthropometric parameters z-scores means in children infected or uninfected with soil-transmitted helminths in Santa Isabel do Rio Negro, Amazonas, Brazil, 2005

\begin{tabular}{|c|c|c|c|c|c|c|c|c|c|c|c|c|}
\hline \multirow[b]{2}{*}{ Variable } & \multicolumn{2}{|c|}{$\begin{array}{c}\text { Ascaris } \\
\text { lumbricoides }\end{array}$} & \multicolumn{2}{|c|}{ Hookworm } & \multicolumn{2}{|c|}{$\begin{array}{l}\text { Trichuris } \\
\text { trichiura }\end{array}$} & \multicolumn{2}{|c|}{$\begin{array}{l}\text { Strongyloides } \\
\text { stercoralis }\end{array}$} & \multicolumn{2}{|c|}{$\begin{array}{l}\text { Giardia } \\
\text { lamblia }\end{array}$} & \multicolumn{2}{|c|}{$\begin{array}{c}\text { Entamoeba } \\
\text { histolytical } \\
\text { E. dispar }\end{array}$} \\
\hline & $\operatorname{Inf}^{2}$ & Uninf $^{3}$ & Inf & Uninf & Inf & Uninf & Inf & Uninf & Inf & Uninf & Inf & Uninf \\
\hline $\mathrm{N}$ & 122 & 175 & 16 & 280 & 74 & 223 & 12 & 218 & 87 & 210 & 36 & 261 \\
\hline WAZ mean & -0.71 & -0.62 & $-1.14^{1}$ & $-0.63^{1}$ & -0.64 & -0.66 & -0.75 & -0.60 & $-0.94^{1}$ & $-0.54^{1}$ & -0.66 & -0.65 \\
\hline $\mathrm{N}$ & 119 & 177 & 15 & 280 & 71 & 225 & 12 & 216 & 85 & 211 & 36 & 260 \\
\hline HAZ mean & $-1.42^{1}$ & $-1.16^{1}$ & $-1.88^{1}$ & $-1.23^{1}$ & -1.34 & -1.24 & -1.65 & -1.18 & $-1.51^{1}$ & $-1.17^{1}$ & -1.38 & -1.24 \\
\hline $\mathrm{N}$ & 119 & 174 & 15 & 277 & 71 & 222 & 11 & 215 & 84 & 209 & 36 & 257 \\
\hline WHZ mean & 0.15 & 0.23 & 0.18 & 0.15 & 0.24 & 0.15 & 0.49 & 0.18 & $0.00^{1}$ & $0.25^{1}$ & 0.29 & 0.16 \\
\hline $\mathrm{N}$ & 81 & 131 & 7 & 204 & 46 & 166 & 11 & 152 & 58 & 154 & 21 & 191 \\
\hline MUACZ mean & -0.34 & -0.26 & -0.31 & -0.29 & -0.22 & -0.31 & -0.62 & -0.26 & & & & \\
\hline
\end{tabular}

1 - $p<0.05$ on analysis of variance (ANOVA). 2 - Inf $=$ infected. 3 - Uninf $=$ uninfected. 


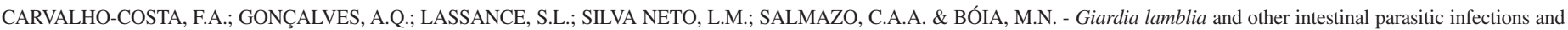
their relationships with nutritional status in children in Brazilian Amazon. Rev. Inst. Med. trop. S. Paulo, 49(3): 147-153, 2007.

Table 5

Multiple linear regression analysis of anthropometric parameters z-scores by Giardia lamblia, Ascaris lumbricoides and hookworm infections; family income strata, age and sex of children in Santa Isabel do Rio Negro, Amazonas, Brazil

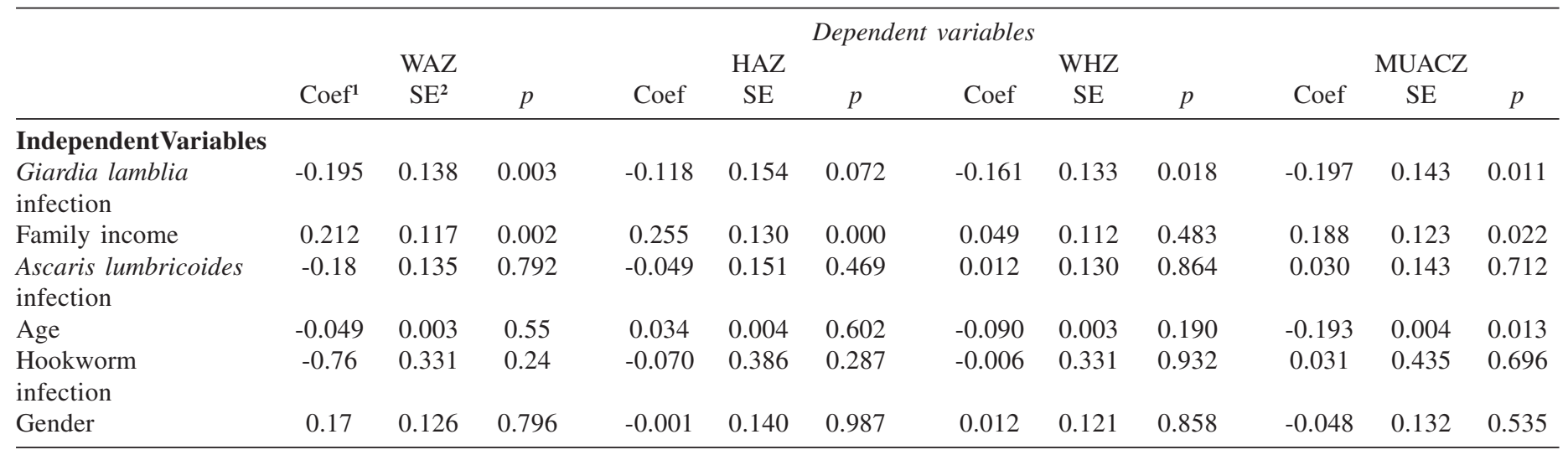

1- Coef $=$ Coefficient. $2-\mathrm{SE}=$ Standard error .

Multiple linear regression analysis showed interactions between G. lamblia infection and WAZ (beta $=-0.195, \mathrm{SE}=0.138, p=0.003$ ), WHZ (beta $=-0.161, \mathrm{SE}=0.133, p=0.018)$ and MUACZ $($ beta $=$ $-0.197, \mathrm{SE}=0.143, p=0.011)$, controlling for age, sex, family income, A. lumbricoides, and hookworm infections (Table 5). Also, the multivariate model showed that the only variable associated with hemoglobin levels was age.

\section{DISCUSSION}

This cross-sectional survey demonstrated the relationships between enteric parasitic diseases and some nutritional indicators in a sample of children living in an urban area in Brazilian Amazon. Data showed an interaction between $G$. lamblia infection and anthropometric parameters, suggesting that this protozoan affects the nutritional status of surveyed children. The study demonstrated that $29 \%$ of the children were infected with $G$. lamblia. These children had lower means for all studied anthropometric parameters on bivariate analysis. Even after adjustment for socioeconomic confounders, sex, age and other intestinal parasitosis, multiple linear regressions showed a significant interaction between $G$. lamblia infection and WAZ, WHZ and MUACZ. Multivariate analysis did not identified interactions between other enteric parasites and nutritional status despite hookworm and $A$. lumbricoides infections were associated with significantly lower means for some anthropometric parameters on the bivariate model. No interactions between intestinal parasitism and hemoglobin levels were observed. According to the worm burden's stratification proposed by MONTRESOR et al. ${ }^{11}, 25.9 \%$ of subjects presenting ascariasis had severe infections (up to 50,000 epg). All children harboring hookworms had light infections (below 2,000 epg). Also, 91.4\% of children with trichuriasis had light infections (below 1,000 epg) and none presented high worm burdens (up to $10,000 \mathrm{epg}$ ). Such data probably contributed to the absence of relationship between those infections and nutritional status.

Other authors showed the relationship between $G$. lamblia infection and undernutrition in Africa ${ }^{10}$, Asia $^{2}$ and Brazil ${ }^{12}$. ERTAN et al. (2002) demonstrated that $G$. lamblia infection is associated with lower serum levels of zinc and iron ${ }^{6}$.

The role of G. lamblia on the etiology of chronic and persistent diarrhea is also recognized ${ }^{1,14}$. Persistent diarrhea and consequent malabsorption seriously affects nutritional status and growth. These conditions are still very common in Brazilian Amazon, affecting Indian children and those with Amerindian ancestry living in urban areas.

Unfavorable nutritional scenarios for Brazilian Indian children have been described in literature, with high frequencies of malnutrition, in surveys carried out in populations living in different stages of contact with the national society (see SANTOS 1993 for a review ${ }^{19}$ ). However, few studies aimed to understand changes occurring on an urbanization background. Rural emigration and urbanization in Amazon represents, in a small scale, demographic tendencies observed on more populated Brazilian regions. In the studied region, people originated from riverine communities, isolated in the forest, had migrated to the municipality's seat, living under very unfavorable conditions, in a context of poverty, low sanitation and high environmental contamination with excreta.

The poorest families, identified in this survey as those without regular wages, plant manioc for flour production, on subsistence agriculture. Liquid and soft foods made only with manioc flour and water, such as chibé and maçoca, are consistently given to infants and children to replace milk, also during weaning. Some other fruits and vegetables are produced by farmers and include macaxeira, banana, pineapple, açai, сириаçu and potatoes. There is no excess production oriented for trading; planted foods are exclusively for familiar consumption. The survey suggests that familiar income strongly influences children's nutritional status and points to the existence of qualitative and quantitative nutritional gaps on available diets for different income groups. Multiple linear regression analysis showed an interaction between HAZ, WAZ and MUACZ and family income group. So, this variable was considered an important confounding factor in the assessment of the influence of intestinal parasitism on nutritional status, once children belonging to the poorest families have probably the worst sanitary conditions and presented a 


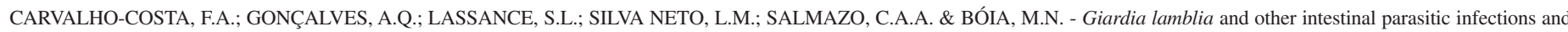
their relationships with nutritional status in children in Brazilian Amazon. Rev. Inst. Med. trop. S. Paulo, 49(3): 147-153, 2007.

higher frequency of enteric parasitosis detection. A. lumbricoides and hookworm infections were significantly more frequent in children belonging to families with no wages. On the other hand, giardiasis did not show an income group distribution, affecting equally children belonging to the three socioeconomic strata. Data from this study suggest that social and environmental factors influence nutritional status in children living in the studied area.

Chronic malnutrition characterized as stunting is very frequent in Indian children living in Amazon. Studies suggest that this form of malnutrition has interrelated determinants that can be understood in a hierarchical structure. Proximal determinants are poor dietary intake and infectious diseases that are affected by family access to water, sanitation, and adequate health services. These conditions, in their turn, are influenced by structural factors at the societal level, within a political-economic context ${ }^{22}$. Our data showed that, although WAZ and WHZ were clearly influenced by G. lamblia infection, HAZ, the anthropometric parameter defining chronic malnutrition, presented a borderline interaction with giardiasis on the multivariate model and a significant association with this parasite on the bivariate analysis. Data suggests that giardiasis can acutely influence weight, probably through malabsorption, but chronic infection can potentially contribute to height deficits, being possibly one of the multiple determinants of the high prevalence of stunting observed in these communities.

This trial contributed to the comprehension of the factors that influence nutritional status of Indian children living in urban areas in Brazilian Amazon. It showed the influence of G. lamblia infection on anthropometric parameters and additionally demonstrated that family income strongly affects children's nutritional status.

\section{RESUMO}

Giardia lamblia e outros parasitas intestinais e sua relação com o status nutricional de crianças de uma área urbana na Amazônia Brasileira

O presente estudo objetivou avaliar a relação entre as parasitoses intestinais, o status nutricional e os níveis de hemoglobina em crianças vivendo em uma área urbana na Amazônia Brasileira. Foi realizado um estudo seccional, obtendo-se dados antropométricos, parasitológicos e socioeconômicos, além de dosagens de hemoglobina através do fotômetro Hemocue ${ }^{\circledR}$, de crianças com idade entre seis e 84 meses. Os dados da antropometria foram expressos como escores de desvio-padrão (escores z) para os parâmetros peso-idade (PI), altura-idade (AI), pesoaltura (PA) e perímetro braquial-idade (PBI). Os exames parasitológicos foram realizados através dos métodos de Ritchie $(n=307)$, Kato-Katz ( $n=278)$, Baermann-Moraes $(n=238)$ e Safranina-Azul-de-Metileno $(\mathrm{n}=307)$. A regressão linear múltipla demonstrou interações independentes entre Giardia lamblia e PI (beta $=-0.195, p=0.003$ ), PA (beta $=-0.161, p=0.018$ ) e PBI (beta $=-0.197, p=0.011$ ), após controle para idade, sexo, renda familiar e infecções por Ascaris lumbricoides e ancilostomídeos. O modelo multivariado demonstrou ainda que a única variável associada aos níveis de hemoglobina foi a idade. O estudo concluiu que a giardíase está associada, nos sujeitos pesquisados, a menores médias para os parâmetros antropométricos estudados e que um controle efetivo das parasitoses intestinais poderia contribuir para o pleno desenvolvimento das crianças na área estudada.

\section{ACKNOWLEDGEMENTS}

We would like to acknowledge Pastoral da Criança leaderships for help with the organization of field activities, to the municipality's administrative staff for support on lodging the research team, to $\mathrm{Mr}$. Laudecir Couto dos Santos for technical assistance and to the people from Santa Isabel do Rio Negro - AM for essential cooperation with the research.

\section{REFERENCES}

1. ALI, S.A. \& HILL, D.R. - Giardia intestinalis. Curr. Opin. infect. Dis., 16: 453-460, 2003.

2. AL-MEKHLAFI, M.S.; AZLIN, M.; NOR AINI, U. et al. - Giardiasis as a predictor of childhood malnutrition in Orang Asli children in Malaysia. Trans. roy. Soc. trop. Med. Hyg., 99: 686-691, 2005.

3. BRASIL. Ministério da Saúde - Política nacional de alimentação e nutrição. Brasília, Ministério da Saude, Secretaria de Políticas de Saúde, Instituto Nacional de Alimentação e Nutrição, 2000.

4. CHAN, M.S. - The global burden of intestinal nematode infections: fifty years on. Parasit. today, 13: 438-443, 1997.

5. DE SILVA, N.R.; GUYATT, H. L. \& BUNDY, D.A.P. - Morbidity and mortality due to Ascaris-induced intestinal obstruction. Trans. roy. Soc. trop. Med. Hyg., 91: 3136, 1997.

6. ERTAN, P.; YERELI, K.; KURT, O.; BALCIOGLU, I.C. \& ONAG, A. - Serological levels of zinc, copper and iron elements among Giardia lamblia infected children in Turkey. Pediat. Int., 44: 286-288, 2002.

7. HADJU, V.; ABADI, K.; STEPHENSON, L.S. et al. - Intestinal helminthiasis, nutritional status, and their relationship; a cross-sectional survey in urban slum school children in Indonesia. Southeast Asian J. trop. Med. publ. Hlth, 26: 719-729, 1995.

8. INSTITUTO BRASILEIRO DE GEOGRAFIA E ESTATÍSTICA - Sinopse preliminar do censo demográfico de 2000. Malha municipal digital do Brasil, 1997. Brasília, IBGE, 2002. http://www.ibge.gov.br/cidadesat/default.php2000 (18/12/2005).

9. INSTITUTO SOCIOAMBIENTAL - Povos indígenas do Brasil, Noroeste Amazônico. http://www.socioambiental.org (10/11/2005).

10- LOEWENSON, R.; MASON, P.R. \& PATTERSON, B.A. - Giardiasis and the nutritional status of Zimbabwean schoolchildren. Ann. trop. Paediat., 6: 73-78, 1986.

11. MONTRESOR, A.; CROMPTON, D.W.T.; GYORKOS, T.W. \& SAVIOLI, L. - Helminth control in school-age children: a guide for managers of control programmes. Geneva, World Health Organization, 2002.

12. MUNIZ-JUNQUEIRA, M.I. \& QUEIROZ, E.F.O. - Relationship between protein-energy malnutrition, vitamin A, and parasitoses in children living in Brasília. Rev. Soc. bras. Med. trop., 35: 133-141, 2002.

13. OBERHELMAN, R.A.; GUERRERO, E.S.; FERNANDEZ, M.L. et al. - Correlations between intestinal parasitosis, physical growth, and psychomotor development among infants and children from rural Nicaragua. Amer. J. trop. Med. Hyg., 58: 470-475, 1998

14. OCHOA, T.J.; SALAZAR-LINDO, E. \& CLEARY, T.G. - Management of children with infection-associated persistent diarrhea. Semin. pediat. infect. Dis., 15: 229-236, 2004.

15. OLNESS, K. - Effects on brain development leading to cognitive impairment: a worldwide epidemic. J. dev. behav. Pediat., 24: 120-130, 2003. 


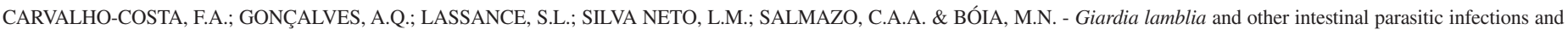
their relationships with nutritional status in children in Brazilian Amazon. Rev. Inst. Med. trop. S. Paulo, 49(3): 147-153, 2007.

16. ONIS, M.; FRONGILLO, E.A. \& BLOSSNER, M. - Is malnutrition declining? An analysis of changes in levels of child malnutrition since 1980. Bull. Wld Hlth Org., 78: 1222-1233, 2000.

17. ORDONEZ, L.E. \& ANGULO, E.S. - Malnutrition and its association with intestinal parasitism among children from a village in the Colombian Amazonian region. Biomedica, 22: 486-498, 2002.

18. QUIHUI-COTA, L.; VALENCIA, M.E.; CROMPTON, D.W.T. et al. - Prevalence and intensity of intestinal parasitic infections in relation to nutritional status in Mexican schoolchildren. Trans. roy. Soc. trop. Med. Hyg., 98: 653-659, 2004.

19. SANTOS, R.V. - Crescimento físico e estado nutricional de populações indígenas brasileiras. Cadern. Saúde públ., 9(supl. 1): 46-57, 1993.

20. SHUBAIR, M.E.; YASSIN, M.M.; AL-HINDI, A.I. et al. - Intestinal parasites in relation to haemoglobin level and nutritional status of school children in Gaza. J. Egypt. Soc. Parasit., 30: 365-375, 2000.
21. STEPHENSON, L.S.; LATHAM, M.C. \& OTTESEN, E.A. - Malnutrition and parasitic helminth infections. Parasitology, 121 (suppl.): S223-S238, 2000.

22. UNITED NATIONS CHILDREN'S FUND/UNICEF - The state of the world's children. Oxford, Oxford University Press, 1998.

23. WATERLOW, J.C.; BUZINA, R.; KELLER, W. et al. - The presentation and use of height and weight data for comparing the nutritional status of groups of children under the age of 10 years. Bull. Wld HIth Org., 55: 489-498, 1977.

24. WORLD HEALTH ORGANIZATION - Report of the UNICEF/WHO Regional Consultation. Prevention and control of iron deficiency anaemia in women and children 3-5. Geneva, UNICEF/WHO, 1999. p. 22-25.

25. WORLD HEALTH ORGANIZATION - A growth chart for international use in maternal and child health care: guidelines for primary health care personnel. Geneva, WHO, 1978.

Received: 16 May 2006

Accepted: 20 October 2006 